\title{
Perancangan Animasi Adaptasi Kisah Hidup Wage Rudolf Supratman
}

\author{
Lidya Riani Ramli dan Nugrahardi Ramadhani \\ Departemen Desain Komunikasi Visual, Fakultas Arsitektur, Desain, dan Perencanaan, \\ Institut Teknologi Sepuluh Nopember (ITS) \\ e-mail: sancokbrancok@gmail.com
}

\begin{abstract}
Abstrak-WR. Supratman sebagai salah satu Pahlawan Nasional yang bergerak dalam bidang kesenian, kisahnya kurang populer dibandingkan pahlawan lainnya. Kisah WR. Supratman telah ada dalam bentuk biografi dan film, namun kurang diminati. Pengadaptasian biografi WR. Supratman melalui pendekatan sudut pandang yang lebih modern, diharapkan mampu menjadikan kisah sejarah WR. Supratman lebih diminati oleh target dari perancangan ini, yaitu remaja. Metode yang digunakan dalam penelitian adalah metode kualitatif serta kuantitatif data primer, dan data sekunder. Metode kualitatif, yaitu observasi, dan depth interview. Studi eksperimen dilakukan untuk eksperimen ke ahli. Metode kuantitatif yaitu kuesioner, dan data sekunder melalui studi eksisting, studi literatur, dan observasi artefak. Tujuan penelitian ini adalah memperoleh konten dan konsep dalam perancangan animasi fiksi adaptasi kisah hidup WR. Supratman yang disukai remaja, baik dari segi visual, dan alur cerita. Kesimpulan yang didapatkan dari perancangan ini adalah, dengan pengadaptasian sejarah WR. Supratman yang memunculkan tokoh fiksi serta percampuran genre drama dan petualangan, berhasil menjadi daya tarik animasi dengan genre sejarah yang sebelumnya sulit untuk dicapai, dan berhasil mengenalkan tokoh WR. Supratman serta meningkatkan kecintaan kepada tokoh pahlawan dengan parameter sejauh mana tingkat anak dalam menghargai sebuah karya seni, keteladanan, moral, dan mengerti perjuangan pahlawan.
\end{abstract}

Kata Kunci-Animasi, Adaptasi, Fiksi, WR. Supratman, Nasionalisme.

\section{PENDAHULUAN}

ILM animasi telah berkembang pesat di dunia, namun di Indonesia perkembangan animasi masih lambat [1]. Perkembangan yang lambat ini disebabkan oleh SDM dan kurangnya konten produksi, padahal Indonesia menyimpan banyak materi budaya dan sejarah yang dapat dijadikan konten animasi. Salah satu konten sejarah yang dimiliki Indonesia adalah kisah pahlawan-pahlawan nasional. Konten pahlawan dapat diangkat menjadi karya animasi karena kurangnya animasi yang mengangkat kisah pahlawan nasional. Wakil Ketua MPR Oesman Sapta menilai, saat ini bangsa Indonesia telah kehilangan nasionalisme. Menurutnya, pudarnya rasa nasionalisme tersebut terlihat saat tidak sigapnya warganegara Indonesia saat menyanyikan lagu kebangsaan Indonesia Raya.

Nasionalisme seringkali diabaikan masyarakat Indonesia. Jiwa bela negara dan kecintaan terhadap negara yang cenderung rendah pada generasi muda Indonesia, menjadikan bangsa Indonesia rawan terhadap degradasi moral. Generasi muda diharapkan mampu meneladani dan belajar dari semangat para tokoh pahlawan yang memiliki jiwa bela negara, dan nasionalisme. Salah satu tokoh pahlawan yang dapat menjadi teladan adalah Wage Rudolf Supratman. Beliau merupakan tokoh pahlawan pergerakan nasional dan ikut berkontribusi untuk memerdekakan
Indonesia dengan lagu kebangsaan yang ia ciptakan. WR Supratman adalah salah satu pahlawan yang bergerak dibidang seni dalam usahanya memerdekakan Indonesia. Saat ini belum banyak kisah tentang pahlawan seni yang diangkat di Indonesia, selain itu selama ini hanya sedikit orang yang menganggap berkarya juga termasuk dalam sebuah perjuangan. WR. Supratman tidak hanya berkarya dalam bidang musik, beliau juga berkarya dalam bidang sastra, dan banyak peristiwa-peristiwa yang dilalui beliau dalam pembuatan karyanya yang kurang diketahui, karena minimnya pembahasan tokoh WR. Supratman dalam buku pelajaran maupun media lain. Bukan hanya karya, sifat dan karakter tokoh WR. Supratman yang pantang menyerah, juga merupakan nilai-nilai positif yang dapat di contoh oleh generasi muda.

Saat ini kisah WR. Supratman telah ada dalam bentuk biografi, dan film biografi, namun bacaan dan film biografi ternyata kurang diminati, terbukti dari jumlah penonton film Wage di bioskop yang hanya mencapai 23.833 penonton. Angka tersebut sangat jauh dari target awalnya yaitu 1000.000 penonton. Saat ini trend pengadaptasian karya sastra ke layar lebar sedang marak [2]. Dengan mengadaptasi dan memberi sentuhan fiksi pada biografi WR. Supratman melalui pendekatan sudut pandang yang lebih modern, diharapkan mampu menjadikan kisah sejarah WR. Supratman lebih diminati oleh target market.

Animasi yang mengangkat konten tokoh pahlawan, dalam hal ini WR. Supratman, dapat menjadi media alternatif yang mampu mengenalkan salah satu kisah sejarah Indonesia yang mulai diabaikan. Keunggulan animasi dalam kemudahan akses dan penyampaian pesan yang lebih inovatif diharapkan mampu mengangkat kembali kisah hidup WR. Supratman melalui gaya penceritaan yang disukai oleh generasi muda, dan menjadikan generasi muda lebih mencintai serta mewarisi nilai teladan tokoh WR. Supratman.

\section{A. Rumusan Masalah}

"Bagaimana merancang film animasi fiksi adaptasi kisah hidup WR. Supratman yang dapat meningkatkan kecintaan sekaligus mengenalkan sejarah pahlawan nasional Indonesia kepada generasi muda?"

\section{B. Batasan Masalah}

Berikut adalah batasan masalah dalam penelitian berdasarkan

identifikasi dan rumusan masalah, agar bahasan tetap berada dalam fokus dan koridor yang jelas:

1. Output perancagan berupa trailer animasi WR Supratman.

2. Animasi dibuat dengan tujuan untuk mengenalkan tokoh WR. Supratman yang ditujukan untuk remaja.

3. Dilakukan adaptasi dan penambahan karakter fiksi pada cerita dari biografi. 
4. Penelitian ini memilih remaja dengan range usia 1318 tahun sebagai sampel.

5. Kisah yang dimuat dimulai dari WR. Supratman memperjuangkan lagu Indonesia Raya, hingga wafat.

\section{Tujuan Penelitian}

Berdasarkan ulasan latar belakang dan rumusan masalah pada penelitian ini, maka adapun maksud dan tujuan penelitian ini adalah, untuk mengenalkan lebih mendalam sifat dan karakter tokoh WR. Supratman sebagai pahlawan Indonesia melalui film animasi fiksi adaptasi kepada generasi muda.

\section{TINJAUAN PUSTAKA}

\section{A. Tinjauan Teori}

Teori yang digunakan akan menjadi landasan dan acuan dalam merancang perancangan baik aspek konten maupun media. Tinjauan dilakukan pada pengertian dan bagaimana membuat sebuah karya adaptasi [3] dan fiksi dengan baik [4]. Kemudian teori perkembangan animasi dan konsepnya yang didapat dari buku karya Ruslan Arief [5], prinsip animasi 2D dari Disney [6], dan teknis animasi oleh Kit Laybourne [7].

\section{B. Studi Konten WR. Supratman}

Riset data sekunder melalui studi literatur pada buku biografi WR. Supratman, "Wage Rudolf Supratman" [8], dan buku biografi Wage Rudolf Supratman yang berisi pelurusan sejarah [9], kemudian analisis pada film "Wage" dan observasi artefak yang merupakan metode kualitatif yang dilakukan dengan cara mengumpulkan dan mengamati artefak eksisting dari peninggalan-peninggalan yang berhubungan dengan WR. Supratman. Bertujuan untuk mendapatkan data sekunder yang berhubungan dengan WR. Supratman sebagai sumber konten dasar dalam perancangan.

\section{Studi Karakteristik Anak}

Mempelajari karakter anak pada usia remaja, karena perancangan animasi ini ditujukan untuk anak remaja. Pada periode ini, anak remaja memiliki karakteristik yang khas jika dibanding dengan periode-periode perkembangan lainnya. Diantaranya, anak mengalami perubahan, mencari jati diri, tidak realistis, dan merupakan ambang masa menuju dewasa.

\section{D.Studi Gaya Gambar}

Ada dua macam gaya atau syle yang sering digunakan dalam pembuatan animasi, yaitu eastern (manga) dan western (cartoon) animation. Kedua gaya gambar ini memiliki perbedaan yang cukup mencolok, terutama dalam penggambaran karakter manusia. Tabel 1 merupakan perbandingan gaya eastern dan western.

\section{E. Tinjauan Animasi}

Animasi yang dipilih untuk ditinjau dan dijadikan acuan adalah animasi dengan genre historical yaitu Anne Franks's Diary, In This Corner of The World, dan Ethel and Ernest. Dari ketiga animasi eksisting ini didapatkan acuan yang akan digunakan dalam animasi sebagai berikut:

$$
\text { Tabel } 1 .
$$

Perbandingan antara eastern dan western

\begin{tabular}{lll}
\hline \hline & \multicolumn{2}{c}{ Western } \\
\hline Gambar yang detail dan lebih & Penggambaran yang dilebih- \\
realistis. Seperti bulu mata, lipatan & lebihkan, seperti kaki yang \\
baju & panjang, wajah bulat sempurna \\
Menggunakan banyak pengambilan & Straight on pengambilan sudut
\end{tabular}

sudut gambar, dan flow yang baik kamera,

Pewarnaan detail, bayangan, dan Pewarnaan solid, kecuali pencahayaan

Banyak menggunakan scene panjang dengan gerakan mulut, minim perpindahan

Dapat ditonton oleh anak-anak maupun lebih dewasa beberapa scene dramatis yang memerlukan detail lebih

Animasi dengan banyak gerakan, perpindahan, dan motion

Lebih sering menargetkan pasar anak-anak

1. Cerita ringan yang menyentuh.

2. Humor yang terselip pada beberapa adegan.

3. Animasi menggunakan gaya ilustrasi anime Jepang (Eastern) dengan pewarnaan cell shading menggunakan outline dan teknik animasi 2D tradigital.

4. Penggunaan warna pastel cerah untuk menunjukkan kesan kuno namun tetap modern.

5. Memberikan keterangan tanggal dan waktu pada pergantian waktu dan bulan.

6. Desain karakter simpel untuk mempermudah penganimasian.

\section{METODE PENELITIAN}

\section{A. Alur Penelitian}

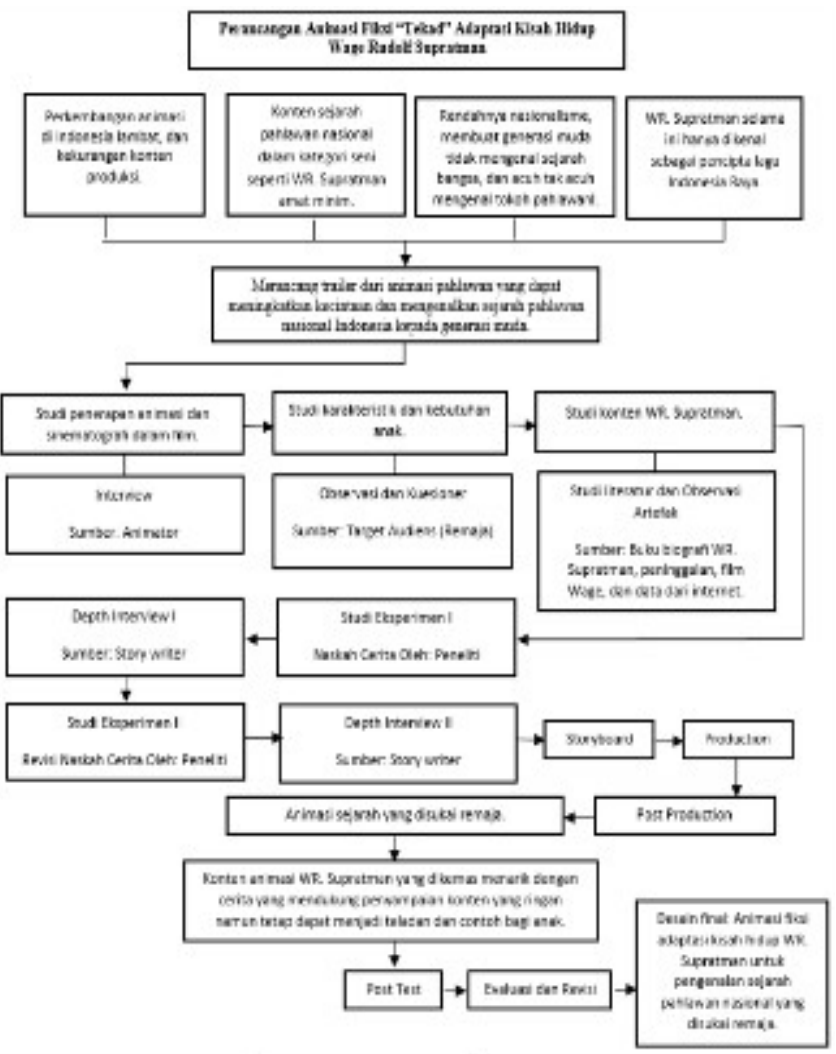

Diagram 1. Bagan alur penelitian.

Metode yang digunakan dalam penelitian adalah metode kualitatif serta kuantitatif data primer, dan data sekunder. Pengaplikasian metode kualitatif, yaitu saat mengumpulkan data lapangan melalui kegiatan observasi, memperoleh pendapat stakeholder melalui kegiatan interview. Studi eksperimen dilakukan kemudian dilanjutkan depth interview ke ahli. Metode kuantitatif digunakan saat melakukan kuesioner dan untuk menguji hasil eksperimen dalam bentuk post test pada target segmen, dan data sekunder melalui studi eksisting, studi literatur, dan observasi artefak.

\section{B. Formulasi Hasil Penelitian}


Membuat formulasi hasil analisis menggunakan metode diagram afinitas, yaitu dengan mengelompokkan ide-ide dari permasalahan yang dibahas untuk mendapatkan kata kunci, dan mengolahnya menjadi sebuah ide besar untuk konsep desain, dan menemukan empat kata kunci berikut ini:

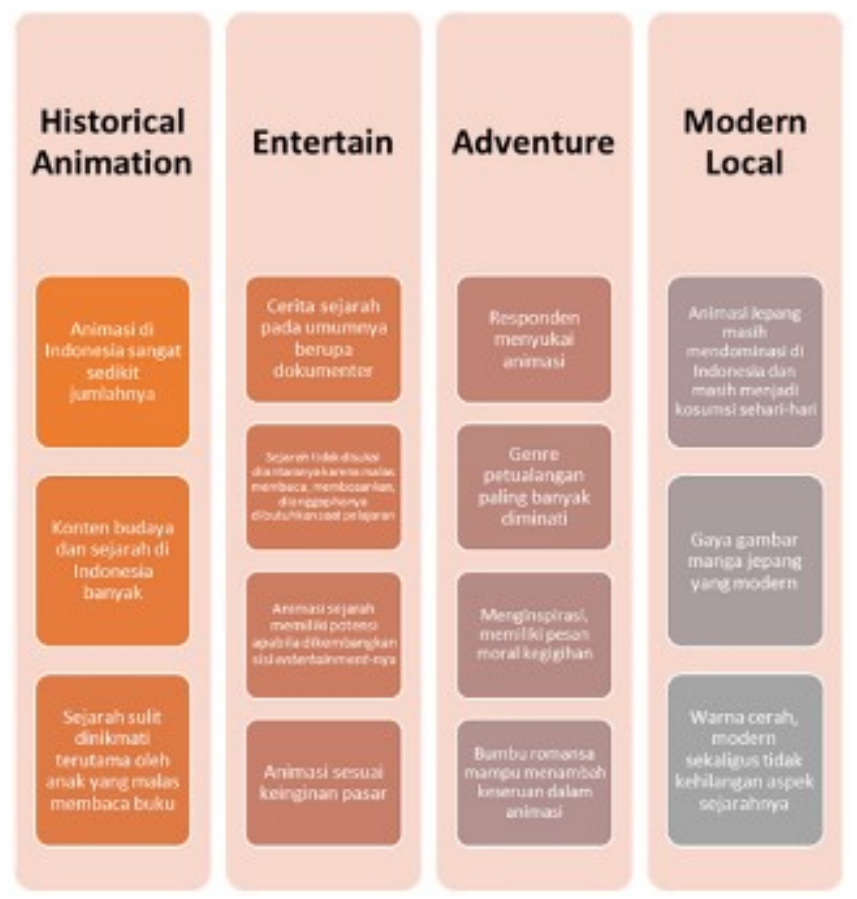

Diagram 2. Formulasi hasil penelitian.

\section{KONSEP DESAIN}

\section{A. Kriteria Desain}

Proses pembuatan karakter berdasarkan foto asli sebagai referensi untuk karakter non fiksi. Berikut adalah alternatif desain karakter WR. Supratman:

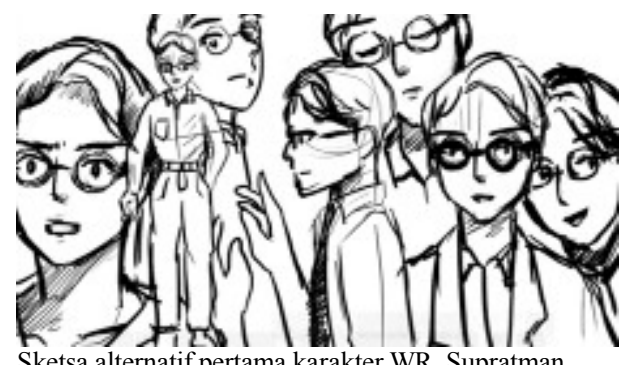

Gambar 1. Sketsa alternatif pertama karakter WR. Supratman.

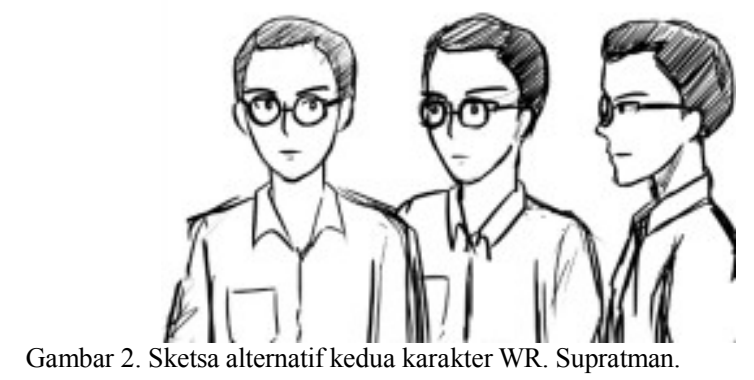

Gambar 2. Sketsa alternatif kedua karakter WR. Supratman.

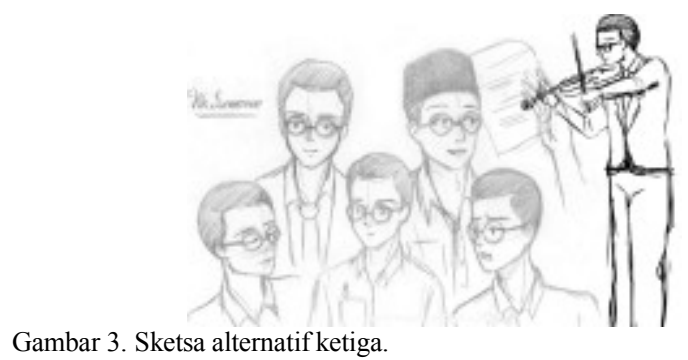

Pemilihan gaya gambar untuk perancangan yang dinilai paling sesuai untuk menggambarkan tokoh sejarah adalah alternative ketiga. Setelah itu pembuatan latar dengan menggunakan referensi foto asli, dan hasil sketsa sebagai berikut:

Gambar 4. Sketsa latar.

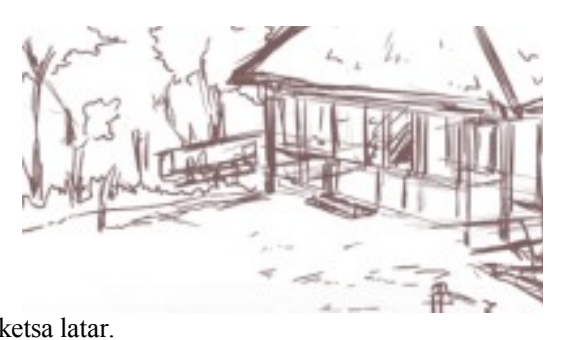

Format animasi Tekad yang digunakan pada perancangan ini memenuhi kriteria untuk ditayangkan di layar lebar.
Dimensi
: 1080 x 1920 pixel
Aspek Rasio: 16:9
Frame Rate : 24 fps
Ekstensi : :mp4
Durasi : 80 menit
Audio : Stereo
Sample Rate: $48 \mathrm{KHz}$
Channel : 5.1 channel
Level Audio: Maks -6dBFs

Animasi dikerjakan dalam bentuk 2D menggunakan teknik animasi tradigital yaitu menggambar frame satu per satu dengan gaya visual utama karakter, dan properti digital cell shading, dan latar dengan gaya visual digital painting. Animasi WR. Supratman ini berdurasi 80 menit. Pengerjaan dimulai dari pembuatan breakdwon alur cerita dan narasi, pembuatan script, pembuatan storyline trailer, script trailer, desain karakter, desain latar, story board, rough key, clean up, coloring, animating, rendering, scoring dan compositing.

\section{B. Konsep Desain}

Berdasarkan formulasi hasil penelitian, masalah terbagi menjadi empat kelompok yaitu Historical Animation, Entertain, Adventure, dan Modern Local. Berikutnya dari kata kunci tersebut ditarik suatu kalimat kunci yang dijadikan dasar konsep desain yaitu "Indonesia Modern and Entertaining Historical Animation”.

\section{C.Konsep Komunikasi}

Komunikasi pada perancangan animasi ini adalah berfokus pada pengenalan tokoh WR. Supratman, sejarah, dan penekanan pada alur cerita dari sudut pandang seorang remaja yang karakternya dibuat mirip dengan kondisi remaja sekarang yang nasionalismenya rendah. Karena membawa cerita sejarah, maka animasi hanya mengambil beberapa kejadian-kejadian utama pada sejarah, tidak seutuhnya seperti biografi, dan menambahkan beberapa adegan seperlunya, sehingga tidak membosankan bagi penonton. Berikut ini adalah informasi-informasi yang disampaikan dalam animasi WR. Supratman: 


\section{D.Konsep Konten Cerita}

Berdasarkan wawancara, konten sejarah dapat menjadi menarik, dengan syarat dibuat menyenangkan, sehingga konten cerita ini tidaklah berupa film dokumenter seperti sejarah pada umumnya. Dengan itu, maka animasi ini mengadaptasi sejarah kisah hidup WR. Supratman dengan menghadirkan sesosok fiksi tambahan yang memiliki cerminan sifat dan karakter yang dekat dengan kebanyakan anak remaja sekarang, bernama Dimy. Dimy, anak SMP yang berasal dari masa sekarang mengalami time travel dan melihat langsung perjuangan seorang pahlawan akhirnya tersadar dan akan memperbaiki sifatnya yang tidak menghargai sebuah upacara.

Animasi ini akan diberikan judul "Tekad", yang menceritakan kisah seorang WR. Supratman yang tidak pernah mau berhenti berkarya, meskipun banyak resiko, dan banyak hal yang menentang dan menghalanginya, serta Dimy yang tersadar akan perbuatannya karena melihat langsung perjuangan WR. Supratman.

\section{E. Konsep Trailer}

Berdasarkan acuan trailer animasi eksisting, konsep trailer "Tekad" adalah trailer yang menampilkan seluruh isi cerita dengan tujuan audiens mengerti jalannya cerita tanpa harus menonton animasi lengkap, namun tetap membuat audiens penasaran dengan bagaimana tokoh utama bernama Dimy menyelesaikan masalah yang dialaminya.

Pesan moral yang ingin disampaikan melalui trailer ini adalah agar audiens mampu untuk menghargai suatu hal mulai dari hal kecil, seperti upacara dan menyanyikan lagu kebangsaan sebagai bentuk rasa terimakasih kepada pahlawan, dengan menampilkan trailer yang menekankan pada penyesalan Dimy yang selalu bermalas-malasan untuk mengkuti upacara dan menunjukkan karakter WR. Supratman yang memiliki tekad untuk terus memperjuangkan lagu kebangsaan, meskipun dihalangi Dimy, kekasih, teman, dan Pemerintah Hindia Belanda.

Trailer ini menggunakan alur maju dengan preview konflik di awal. Trailer Tekad memiliki plot point sebagai berikut:

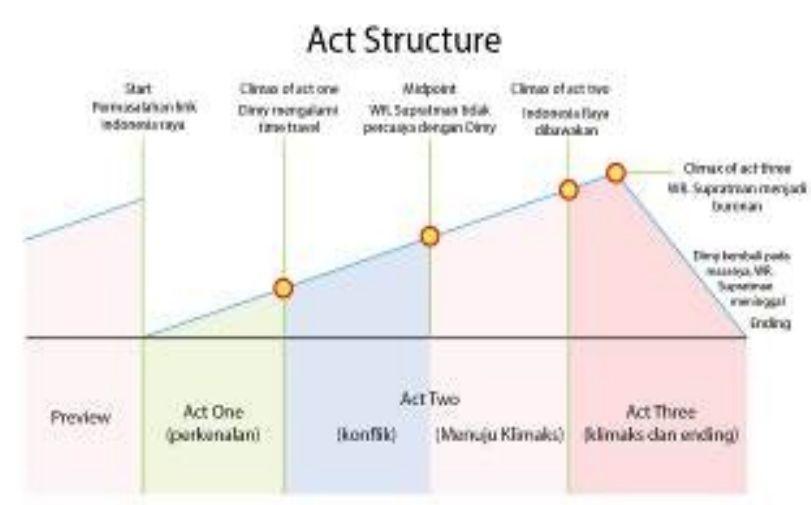

Diagram 3. Grafik plot point Tekad.

Preview: Menunjukkan masalah yang terjadi akibat lirik Indonesia Raya

Perkenalan: Dimy terpaksa mengikuti upacara dan tertidur saat upacara berlangsung.

Konflik: Dimy mengalami time travel dan bertemu WR. Supratman. Dimy berusaha menghentikan WR. Supratman yang akan membawakan lagu Indonesia Raya untuk pertama kali di Kongres Pemuda.
Menuju Klimaks: WR. Supratman tidak percaya dengan peringatan Dimy, dan tetap membawakan lagu Indonesia Raya.

Klimaks: Lagu Indonesia Raya dianggap mengancam, WR. Supratman diburu, dan harus meninggalkan Batavia. Namun pelariannya ditemukan.

End: WR. Supratman meninggal karena penyakit yang menyerangnya saat di penjara.

Berikut adalah grafik plot point trailer "Tekad"

\section{F. Konsep Visual}

1. Karakter

Berikut ini adalah karakter-karakter yang akan muncul di dalam animasi "Tekad":

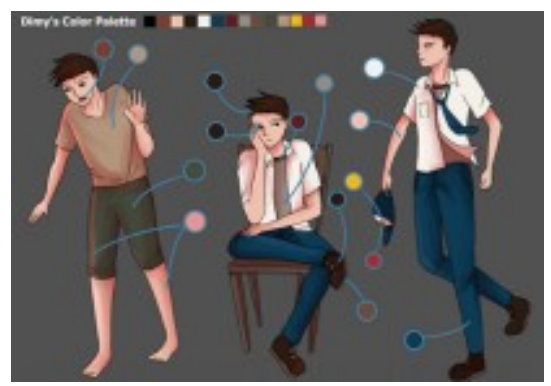

Gambar 5. Desain Karakter Dimy.

Dimy adalah siswa yang bandel dan nakal. Saat upacara bendera seringkali menggunakan berbagai macam alasan untuk absen. Hal yang tidak terduga terjadi di saat upacara. Dimy berkunjung ke masa lalu dimana ia akhirnya sadar akan sebuah perjuangan, dan merubah sikapnya perlahan.

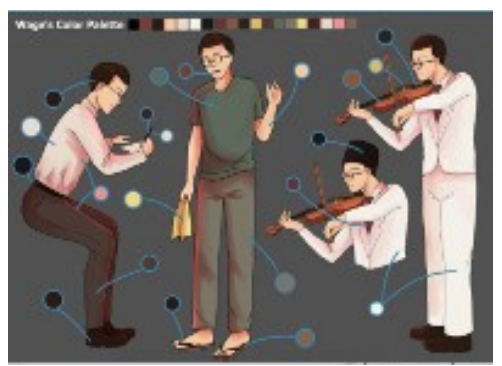

Gambar 6. Desain Karakter WR. Supratman.

WR. Supratman, pencipta lagu kebangsaan Indonesia, berada di masa saat ia sedang mati-matian berkarya untuk bangsa Indonesia, namun tiba-tiba muncul Dimy yang berasal dari masa depan, untuk mencegahnya agar tidak berkarya karena suatu hal. WR. Supratman tidak percaya begitu saja.

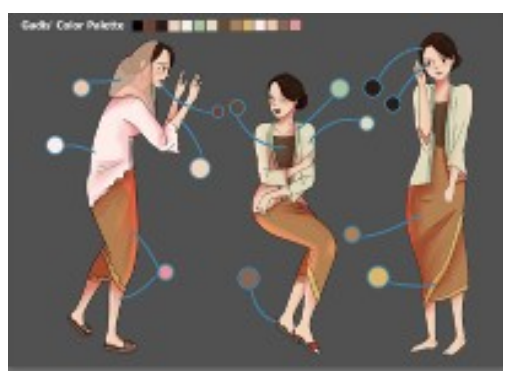

Gambar 7. Desain Karakter Gadis.

Gadis, wanita ini adalah sosok yang dicintai oleh WR. Supratman, dan selama ini selalu mendukung WR. Supratman dalam berkarya. Namun kemunculan Dimy membuatnya khawatir akan WR. Supratman yang terus berkarya. 


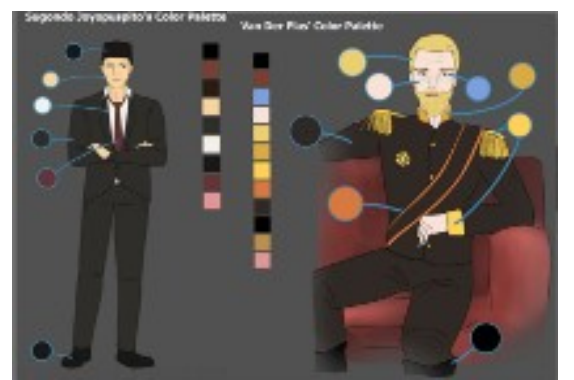

Gambar 8. Desain Karakter Sugondo Joyopuspito dan Van Der Plas.

Sugondo Joyopuspito, ketua Kongres Pemuda II. Ia sempat tidak mau memberi izin kepada WR. Supratman untuk membawakan lagu Indonesia Raya pada saat kongres, karena khawatir perwira polisi Hindia Belanda menghentikan jalannya kongres akibat lirik lagunya.

Van Der Plas, salah satu tokoh antagonis Belanda yang duduk di pemerintahan. Ia adalah orang yang pertama kali membaca lirik lagu Indonsia Raya, sehingga terus meneror WR. Supratman untuk segera ditangkap dan memusnahkan karya-karyanya yang dianggap sebagai ajakan untuk memberontak.

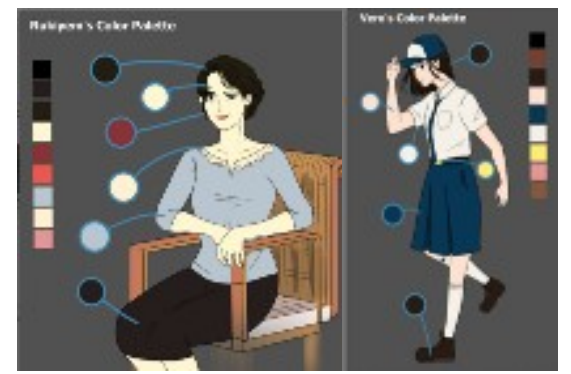

Gambar 9. Desain Karakter Rukiyem dan Vero.

Rukiyem, kakak perempuan WR. Supratman, sangat menyayangi WR. Supratman karena sejak kecil paling akrab dengannya. Ia embantu WR. Supratman yang sedang melakukan pelarian dari polisi Hindia Belanda dengan memberikan tumpangan untuk tinggal.

Vero, Teman wanita Dimy, memaksa Dimy untuk ikut upacara karena sudah berkali-kali tidak ikut serta. Berharap Dimy berubah.

2. Latar

Di dalam animasi terdapat berbagai tempat yang menjadi lokasi pelataran. Latar menggunakan konsep visual berdasarkan referensi dari observasi artefak, yaitu bangunan, suasana, dan properti Indonesia sekitar tahun 1920-1940-an.

Konsep ilustrasi untuk latar yaitu menggunakan teknik digital painting dengan background tanpa outline untuk alam, seperti rumput, pohon, dan tanah, dan menggunakan outline bertekstur untuk bangunan dan benda-benda lainnya dengan pemilihan warna turunan dari warna dasar, agar nampak semipainting dan tidak menyatu dengan karakter. Pemberian shading dan pencahayaan tergantung tempat dan suasana. Berikut adalah konsep latar, beserta teknisnya:

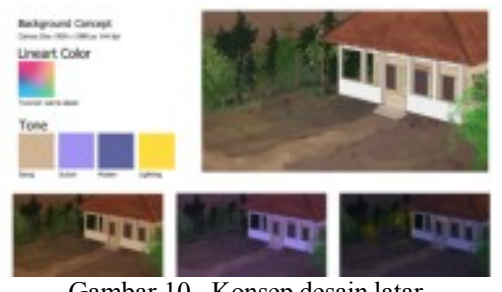

Gambar 10. Konsep desain latar

\section{Tipografi Judul}

Tipografi judul terpilih menggunakan font tebal tanpa kaki, bertujuan menunjukkan karakter yang kuat dan modern. Terdapat biola yang menggantikan huruf "A", yang masih berhubungan dengan WR. Supratman.

\section{$\mathrm{Aa} \mathrm{Bb}$ Cc Dd Ee Ff Gg Hh li Jj Kk LI Mm Nn Oo Pp Qq Rr Ss Tt Uu Vv Ww Xx Yy Zz 1234567890 \\ Mobsters Regular}

Penggunaan judul pada movie, sebagai berikut dengan cahaya merah yang berarti berani dan juga kuat.

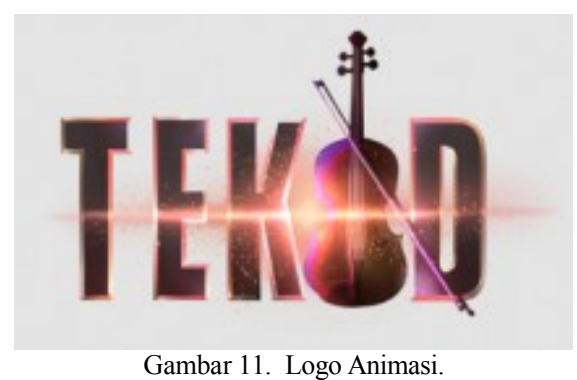

4. Tangkapan Layar

Berikut ini adalah hasil akhir animasi yang berupa tangkapan layar beberapa scene dan shot.

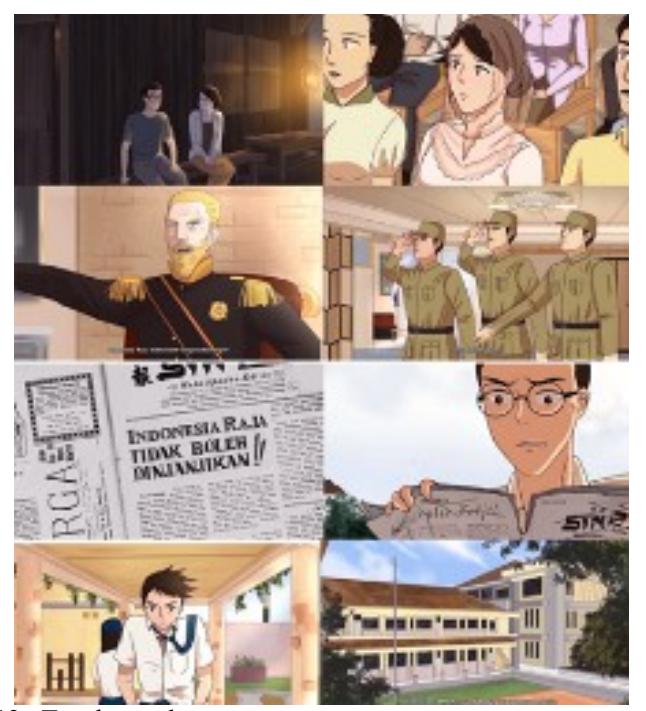

Gambar 12. Tangkapan layar.

\section{G.Konsep Pengembangan}

Berdasarkan kriteria desain animasi Tekad, animasi dengan durasi 80 menit (1 jam 20 menit) dan rating PG-13 akan ditayangkan di bioskop Cinema 21 dan Cinema XXI tipe Deluxe di seluruh Indonesia, dengan poster film sebagai berikut:

Gambar 13. Poster Film Animasi.

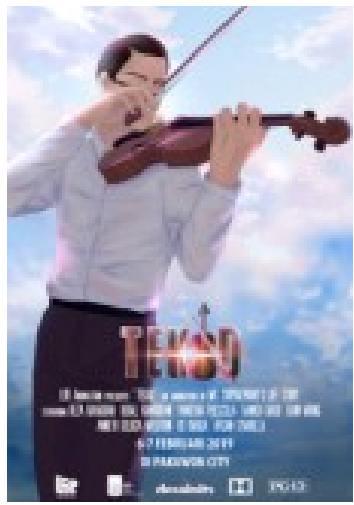


Selain akan dibuat full movie-nya, perancangan ini akan dikembangkan ke dalam beberapa media, hal ini bertujuan untuk kepentingan promosi agar animasi yang telah dibuat lebih dikenal orang, serta bertujuan untuk kepentingan bisnis untuk meraup keuntungan.

Berikut adalah konsep pengembangan yang akan dilakukan

1. Media Lain

Animasi ini akan dikembangkan dalam beberapa media lain yang disukai oleh remaja, salah satunya merchandise berupa jaket, kaos, dan buku. Selain itu animasi ini juga dapat dikembangkan dalam bentuk komik digital untuk platform webtoon.

2. Target Audience Lain

Perancangan ini akan dikembangkan untuk target segmen berbeda, yaitu anak-anak Sekolah Dasar untuk konten pahlawan yang lebih sesuai untuk disajikan kepada segmen anak.

3. Genre yang Berbeda

Pada film animasi selanjutnya animasi pahlawan ini dapat berganti genre sesuai dengan trend yang disukai oleh remaja pada saat itu, sehingga sebagai sebuah animasi bermuatan sejarah, tidak kalah dengan animasi yang lain.

\section{V.KESIMPULAN DAN SARAN}

\section{A. Kesimpulan}

Kesimpulan dari laporan perancangan animasi fiksi "Tekad" adaptasi dari kisah hidup WR. Supratman adalah masalah nasionalisme yang selalu menjadi konten yang dibahas setiap hari kemerdekaan atau hari pahlawan yang mengatakan bahwa rendahnya nasionalisme, seperti tidak menghargai upacara pada kalangan remaja dapat menimbulkan degradasi moral.

Animasi sebagai media yang saat ini sangat mudah diakses dan dapat diterima oleh banyak kalangan, dapat menjadi media alternatif untuk mengatasi masalah dengan mengenalkan tokoh pahlawan yang memiliki karakter dan sifat positif untuk menjadi panutan remaja muda.

Pengadaptasian sejarah WR. Supratman menjadi animasi "Tekad" dan memunculkan tokoh fiksi dengan karakter yang dibuat mirip dengan keadaan remaja sekarang, serta sejarah dengan percampuran genre drama dan petualangan yang saat ini tengah digandrungi remaja, berhasil menjadi daya tarik dengan penyampaian yang berinovasi. Sejarah memang belum banyak diangkat menjadi sebuah konten dalam animasi namun dengan adanya modifikasi cerita, sebuah konten sejarah dalam animasi dapat disamarkan, sehingga mampu menarik pasar yang sebelumnya sulit untuk dicapai.

Berdasarkan Post Test yang dilakukan terhadap lima siswa SMAN 8 Surabaya, diperoleh hasil sebagai berikut:

1. Visual animasi berhasil membuat responden tertarik untuk menonton full movie Tekad.

2. Setelah membaca sinopsis dan menyaksikan trailer, responden mengerti perjuangan seorang WR. Supratman yang telah berjuang untuk Indonesia, dan secara tidak langsung, menjadi lebih mengenal sosok WR. Supratman.

3. Responden mampu mengambil nilai-nilai positif pada tiap-tiap karakter, seperti tokoh Dimy yang awalnya meremehkan pahlawan namun akhirnya mengubah sikapnya, dan WR. Supratman yang terus gigih pada pendiriannya.

4. Responden menunjukkan empatinya kepada tokoh WR. Supratman dan mengatakan akan lebih menghargai suatu hal kecil, seperti lebih menghargai proses upacara bendera dan lebih menghayati saat menyanyikan lagu Indonesia Raya.

5. Responden mengharapkan dapat lebih banyak menonton film tentang sejarah yang disajikan seperti animasi Tekad, baik dari segi visual, maupun konten.

6. Responden menginginkan cerita dengan happy ending.

Meskipun dengan adanya animasi ini, tidak sepenuhnya dapat langsung merubah pandangan remaja terhadap nasionalisme, namun setidaknya mampu memberi sedikit pelajaran untuk menghargai arti sebuah karya dan perjuangan, serta semakin mengenal pahlawan.

\section{B. Saran}

Perancangan animasi Tekad ini masih banyak yang perlu diperbaiki, terutama pada konten cerita yang dibuat terlalu pendek oleh penulis karena terpaku pada aturan minimal durasi pembuatan animasi 30 menit, meskipun pada akhirnya perancangan dieksekusi dengan trailer berdurasi lima menit.

Terdapat beberapa hal yang belum sempat dilakukan oleh penulis pada perancangan, yaitu:

1. Konsep desain mulai dari desain karakter, dan latar hanya yang muncul pada trailer, bukan animasi penuh, begitupun dengan storyboard.

2. Teknik sinematografi yang belum maksimal untuk menampilkan kemegahan sebuah trailer.

3. Cerita yang belum sempurna, dan masih banyak celah, karena penulis lebih berfokus pada teknis animasi.

Harapan kedepannya terhadap animasi ini adalah:

1. Mengembangkan cerita dan melakukan riset lebih dalam terhadap konten yang dibahas, berkolaborasi dengan penulis sehingga cerita yang dibawa lebih berbobot dan memiliki alur yang baik.

2. Mengembangkan karakter-karakter seperti Dimy, yang memiliki banyak kesamaan dengan kondisi remaja sekarang, sebagai bisnis IP (Intelectual Property) yang tengah marak di dalam dunia ilustrasi seperti video pendek, komik, game, boardgame, dan merchandising berupa kaos, tas, dan lainnya.

Apabila suatu saat film animasi ini dapat direalisasikan, akan dikerjakan secara tim, dan durasi dapat ditingkatkan sehingga cerita yang dimuat lebih banyak dan beragam, serta mengajak kolaborasi dengan IP lain yang sudah dikenal oleh kalangan luas untuk membuat animasianimasi baru dan mengembangkan cerita yang terinspirasi dari sifat dan karakter pahlawan lain dan menambahkan unsur modern dan kekinian agar menarik lebih banyak audiens.

\section{DAFTAR PUSTAKA}

S. Cavalier, "The World History of Animation," California, 2011. S. Riyadi, "Penggunaan Film Adaptasi sebagai Media Pengajaran Sastra," Depok, 2014.

P. Sudjirman, Memahami Cerita Rekaan. Jakarta: Pustaka Jaya, 1988.

B. Nurgiyantoro, Teori Pengkaji Fiksi. Yogjakarta: Gadjah Mada University Press, 2002.

A. Ruslan, Animasi, Perkembangan dan Konsepnya. Bogor: Ghalia Indonesia, 2016.

R. Disney, From Pencils to Pixels: Classical Techniques for Digital Animators. USA: Focal Press, 2006. 
[7] K. Laybourne, "The Animation Book: A Complete Guide to Animated." 1998.

[8] B. Sularto, "Wage Rudolf Supratman," Jakarta, 2012.

[9] A. C. Hutabarat, Wage Rudolf Supratman: Meluruskan Sejarah dan Riwayat Hidup Pencipta Lagu Kebangsaaan Republik Indonesia "Indonesia Raya" dan Pahlawan Nasional. Jakarta: Gunung Mulia, 2001. 